\title{
Economic and Legal Consequences of Concluded Apparent Legal on National Interests in Montenegro
}

\author{
Draginja Vuksanoviće 21
}

\begin{abstract}
Concluding contracts on long-term leases of state-ownedproperties, beaches and bathing grounds should bring aboutpositive economic effects through the payment of lease fees and the construction of tourist complexes, which in turn should be reflected on the development of tourism, and therefore on a better quality of life of citizens. In order to have legal effect, a contract as a legal transactionmust be concluded in accordance with positive legal regulations. The respect for the institution of public order is the only condition limiting the fundamental principle of thelaw of obligations - the freedomof contract (autonomy of will). Through a detailed legal analysis, we want to draw attention to the examples of contracts on long-term leases that are unlawful. It is a particular type of apparent legal transactions (simulated contracts), because inconcluding contracts on long-term leases of state-ownedproperty, leasesare simulated in public, while the contracts actually contain elements of sales. It is particularly interesting that the lessor in the concluded contracts is a relevant state authority ( $a$ ministry), on whose behalf the contract is signed by an authorized representative who had also led the negotiations with foreign investors. The consequences of such contracts negativelyinfluencethe economic development, tourism industry, and therefore also the standard of living of citizens.
\end{abstract}

KEY WORDS:Long-Term Lease, Economic Consequences, Legal Consequences, State Interests, State-Owned Property, Simulated Transactions, Corruption

JEL: L83, K12

UDC: $334.728(497.16)$

347.23

COBISS.SR-ID 238311692

\footnotetext{
${ }^{21}$ Faculty of Law of the University of Montenegro, Podgorica, Montenegro, e-mail: draginjav@t-com.me
} 


\section{INTRODUCTION}

Our study refers to the analysis of the provisions of contracts which a competent national authority, in our case the Ministry of Sustainable Development and Tourism of Montenegro, concluded with foreign investors. These are long-term lease contracts of state-ownedproperty (beaches, bathing grounds, islands), which were concluded with the intentionof valorizing these properties through foreign investments that contribute to the renewal of these resources, the construction of tourist complexes, and therefore the development of the tourism industry in Montenegro. The goals set in this way should be achieved if such valorization is arranged on the basis of legally concluded contracts. However, research has shown that in the contracts on long-term leases, unlawful provisions areimplemented. If these provisions are repeated in each contract (as a fixed form), a logical legal question is put forwardregarding what wasmeant to be achieved through the conclusion of such contracts. It is an illicit causa (cause), which represents a form of corruption.

\section{THEORETICAL BASES}

If any of the essential terms of the contract are defined in a way that is contrary tothe established public order, the legal transaction is unlawful and the sanction of nullitymust follow. It is a thin line between the illegal andthe immoral legal affairs, especially in the cases where a single legal transaction offends the institution of public order. Whereas in the case of illegal transactions, one element of a legal transaction is contrary to the explicit regulation of the law, in immoral legal transactions the contents of these legal transactions are contrary to moral attitudes, and thus they also represent offencesagainst the institution of public order ( Gams,1972). Public orderentails a set of principles on which the existence and duration of a legally organized community is based, and which are articulated through coercive legislation and moral imperativeswhich must be respected by all parties in their relations under the threat of sanction of nullity and from which they cannot derogate (Perović, 2010).

The procedure of concluding long-term leases of state-owned property in Montenegro entails that the contract is concluded between two parties, the Ministry of Sustainable Development and Tourism of Montenegro (the lessor) and a Foreign Investor (the lessee). In order for these contracts to begin producing legal effects, it is necessary that the Parliament of Montenegro decides on accepting these contracts with a majority of votes (41 Members of Parliamentout of the 81 ones elected in parliamentary elections), Rules of Procedure of the Parliament of Montenegro (2012). The decision of the Parliament must be made because the Law on State Property stipulates that the property owned by Montenegro or a municipality may be contractually leasedfor up to 30 years subject tothe approval of the Government, i.e.a competent municipal authority, and for up to 90 years subject to the approval of the Parliament, Law on State Property of Montenegro (2011).In our research, we dealt with the interpretation of the provisions of contractswitha lease period longer than 30 years, which require an adoption of a decision in the Parliament. It is in the interest of the state and its citizens that the decision on the valorization of state resources for a period longer than 30 years is brought by the Parliament, but it is quite another question whether the adoption of such decisions actually protects national interests or merely serves as a "cover" that conceals those individuals who concluded void contracts with foreign investors on behalf of the relevant ministry and the Government of Montenegro. Our research is centered on answering this question, focusing on the interpretation of the provisions of the contracts on long-term leases of stateownedproperties. One of the concluded contracts treats the purchase of a site along with other nominate contracts, on long-term leases, communal equipping of the site.It is contrary to the 
norms of the Law on Obligations of Montenegro to treat a sale and purchase contract as a mixed contract, the Law on Obligations of Montenegro (2008). It is logical to ask what motives and incentivesguided the contracting parties (in particular the representatives of the competent state authority) in the conclusion of these, in their legal nature apparent legal transactions. Apparent legal transactions simulate (conceal) the real intention of the parties - especially of those parties that conclude them from a position of authority - tomake a profit through an established pattern of corruption for themselves and not for the citizens and the state. The violation of moral and legal norms embodied in bribery and corruptionhas unfortunately become a normal occurrencein today's society (Petković,Petković, 2012).

\section{ECONOMIC AND LEGAL EFFECTS OF THE CONTRACT ON THE VALORIZATION OF STATE-OWNEDPROPERTY}

In the analysis of thecontracts on long-term leases of state-ownedproperty, we have arrived to the conclusion that these contracts not only contain elements of sale, but that some of the provisions of these contracts infringe the status of sovereignty guaranteed by the Constitution of Montenegro(The Constitution of Montenegro, 2007). Legal violence manifested through the examples of contracts that derogate from the Constitution and the laws of the country has resulted in personal enrichment at the expense of the state and citizens. In the examples that we examined, we found out that it was the case of an illicit cause that constitutes the reason for the nullity of legal transactions.

\section{ABOUT THE CONTENT OF THE CONTRACT WHICH IS THE SUBJECT OF OUR RESEARCH}

The first contract that was the subject of our research, towhich we referredin the introduction as to a mixed Contract of Sale, was nominated as the Contract of the Sale and Purchase with Investments of the Real Estate "Kraljičina Plaža" (the Queen's Beach), with the supporting documents (No. 08-755/3). What we first notice is that the subject, as an essential condition of the contract, is defined as follows: "The subject of this contract are, sale and purchase of land in the Budva and Bar areas, the Contract on the Long-term Lease of a Coastal Zone (Kraljičina PlažaQueen's Beach); the Contract on the Communal Equipping of the Site, and other relevant contracts". Legal theory acknowledges the concept of complex contracts through mixed contracts, the merging of two or more contracts; however the Law on Obligations does not acknowledge it, Law on Obligations (2008). One doesnot need to be a lawyer to know that the subject of a contract cannot be a second, or even several more contracts. When it comes to the sale of the location of Dubovica in the hinterland of the Queen's Beach, the majority of the members of the Tender Committee of the Municipalities of Bar and Budva made the decision to sell $1 \mathrm{~m}^{2}$ of the location at the price of $€ 50$, while the assessment of the competent authority for the real estate and cadasteraffairs amounted to $63.04 € / \mathrm{m}^{2}{ }^{22}$ The decision of the tender committee is therefore unlawful, because the Law on State Property of Montenegro provides that the value of immovable property owned by Montenegro shall be estimated by the administrative body responsible for cadastral affairs. Another authorized body may exercise the appraisal of the property only if the competent authority for cadastral affairsdefines a smaller amount than that other authority, and not vice versa, Law on State Property of Montenegro (2011).If we consider that the object of the sale was a piece of non-urbanized land, and that the obligation of the Bar and Budva municipalities was to arrange for the bringing of infrastructure to the

\footnotetext{
${ }^{22}$ Decision of the Tender Committee of the municipalities of Bar and Budva, n. 08-755 of 17/04/2014
} 
specified location, a lawful sale of state-owned property would entail that, based on the General Urban Plan (GUP), a Detailed Urban Plan DUP was adopted, the land was restored to its purpose, and finally an assessment of value was made. In our case, the procedures were done quite contrary to the rules of the profession and to the interests of the municipalities and the state, and what is more,the proposal was to sell the land below the price for which the estimate was given by a body authorized by law to do so. Such sale of non-urbanized land represents a typical example of a form of corruption - the systemic corruption. In the cases of systemic corruption, a connection is established between the financial lobby, organized crime and politicians. Through their actions, these people undermine the entire socio-economic system,(Petković, Petković,2012). As the subject of the contract, this sale is complementedby the Contract on the Long-term Lease of the Queen's Beach, which is locatedat the foot of the site. This contract contains provisions contrary to the Constitution and to the laws of the State of Montenegro. In one of the provisions of the Contract, a regime of controlled access is established in the maritime zone, stating that the site is available only to club members and guests of the tourist facilities, without specifying whomay become a member of the club and under which conditions. ${ }^{23}$ The Law on State Property allows access to bathing areas and the coast for all citizens without any permits and restrictions, the Law on State Property (2011). The contract stipulates that the foreign investor would not be bound by the possible amendments to the Law in the Montenegrin Parliament if they are not in his interest, while amongst the relevant national authorities the access to the siteis allowed only to fire-fighting units, ambulance and the police. Tax and sanitation inspections are not allowed access. The abovementioned provisions of the contract derogate from the status of sovereignty of the state and represent typical examples of the practice ofexterritoriality, used in international law to describe the exclusion not only of certain individuals, but also of institutions and areas from the jurisdiction of the state in which they are located.It is almost incredible to imagine a provision of acontract which derogates from the Constitution of a state by taking away its sovereignty in a way that prohibits access to not only the beach, but also to the maritime zone of the Queen's Beach and the Site, and in relation to which the investor will not be bound either bythe decisions of the Parliament of Montenegro or by the Tax and Sanitary inspections' powers to carry out inspections. The Contract on the Long-Term Lease of the Queen's Beach also includes a provision under which the lessee (the foreign investor) may without the consent of the lessor (a Ministry in the Government of Montenegro)sub-lease the leased propertyto a third party. This is contrary to the Law on State Property, which prohibits subleasing property without the consent of the lessor, as stipulated in Article 39, par. 7 of the Law on State Property (2011). All the abovementioned provisions of the contractthat are contrary to the Constitution of Montenegro and to the Law on State Property, as well its elements of exterritoriality, are also contained in the Contracton the Long-term Lease of the Lastavica island with the Mamula fortress, the only difference being the duration of the lease. In the case of the lease of the Queen's Beach, the duration of the lease is 90 years, while for the island it is determined for the period of 45 years ${ }^{24}$. In the case of the Queen's Beach - wherethe location of Dubovica issold at the price of $50 € / \mathrm{m}^{2}$, with a commitment of the municipalities to arrange for the bringing ofthe infrastructure which would restore the site to its purpose - when one of the most beautiful pearls of the Montenegrin coast is leased for 90 years, a logical question arises, namely in what way is this done in the "national interest and the interest of the citizens"? The answer to these questions is provided in the contract provisions concerning the permission to register the property clause(clausulaeintabulandi). The clausula intabulandi is a statement with which the previous owner agrees to be deleted from the registry so that the new owner is registered in the cadaster; the Law on Property Relations of Montenegro (2009).This clause is one of the essential conditions for registration. It has no effect on the obligation rights, such as the lease, but only on propertyrights, Rašović, Land Registry Law (2012). Given that the clause of the statement on registration has no effect on the obligation rights, then the logical

\footnotetext{
${ }^{23}$ Draft of the Contract on the Long-Term Lease of the Queen's Beach, n. 08-755/3 of 17/04/2014

${ }^{24}$ Proposal of the Decision on the long-term lease of the location Lastavica Island with the Mamula Fortress, Municipality of Herceg Novi, n.08-137/3 of 5 March 2015
} 
conclusion would be that it does not matter if it is in the contract. However, not only is the statement of registration included in both contracts, but it is defined in them as having the effect of the final acquisition of rights. Only a property right can be acquired finally, given that the obligation rights are narrower and of limited duration.If to thiswe add the provisions of the contract, which, contrary to the norms ofthe Law on Coastal Zone (1992)convey to the lessee the right to use the site without the necessary permits of the public company "Coastal Zone", and, contrary to the Law on Ownership Rights, the right to add the prefix "exclusive"when qualifying itsright of use (while only the right of property may be exclusive), then it is not a lease we are dealing with, but a disguised sale. And, what else could a90-yearlease be, with an underpriced sale of location?! It is a sale for next to nothing, or a gift to a foreign investor. It is a signature that is sold, while state-owned property is given away.When it comes to the contract on the lease of the island, Montenegro would on the basis of this lease receive an annual income of $€ 48,000$, which represents the price of $1.5 € / \mathrm{m}^{2}$, which is a smaller amount than the one that the "Coastal Zone" receives from leasing any other beach. This contract also contains (provision 21.1) according to which the lessee "is and will be the full owner of movable and immovable property of the whole Resort". The lessee and the sub-lessee were also provided with the possibilityto take a bank loan and put the island under mortgage (24.4 of the Contract). A logical and legal question comes up: if the lessee takes a loan from the bankand for the purpose of securing it puts a mortgage on the island which is state-owned property of Montenegro, and then does not pay off this loan, what will happen?The bank will take the island away and sell it to a third party. At this point, we are not taking into consideration to which third party, because our interest here is in the legal and economic effects, i.e. the non-effects of legal transactions concluded in this way. When it comes to the implementation of the project of the Mamula Island, it is very interesting to noticehow according to the contract, the hotel is supposed to have 23rooms and that the whole resort would employ a total of 200 workers. A beautifulstory, if it were not for economics and mathematics. Let us take the example of an employee who receives 430 euros - the average salary and that it is the obligation of the employer to additionally pay with this amountthe contributions per employee in the amount of 350 euros. If the foreign investor announced that in the first ten years he would pay to the country the amount of 2.8 million euros for the disbursement of insurance contributions for the employees, then this amount can cover only about 70 jobs. On the other hand, we also have the Proposal of the Decision accepting the Contract on the Lease of Hotels in the Miločer Park (Proposal of the Decision n.08-2436/3 of 23 October 2015), which also contains all the provisions on the renunciation of sovereignty, and the restricted access to the coast and the bathing zones, where only villa owners would be permitted. Instead ofa development investment project of constructingan elite five-star hotel in the Miločer Park, as it should be done in the interest of national development and the tourism industry, it has been planned to construct a condo hotel and five villas that would be privately owned but built on state-owned land. The villas would be built on the surface area of $12,592 \mathrm{~m}^{2}$. They would be privately owned, and the land beneath them would be under a long-term lease for the period of 90 years ${ }^{25}$. Given that in this contract toothere is the clausula intabulandiwith the effect of the final acquisition of rights, it is clear that once again we have a simulated lease, except that in this legal transaction the lease fee is not precisely determined, but determinable only in principle, which is contrary to the Law on Obligations (2008).

\footnotetext{
${ }^{25}$ Proposal of the Decision accepting the Contract on the long-term lease of 'Kraljičina Plaža - Queen's Beach" in the Miločer park, Budva, n.08-2436/3 of 23 October 2015. NB: In this work, the term "Kraljičina Plaža - Queen's Beach" is mentioned in two legal transactions. One concerns the beach next to Čanj, and the other the name of the hotel in the Miločer Park.
} 


\section{CONCLUSION}

Simulated contracts are the legal transactions that contain an illicit cause. The illicit cause characterizes unlawful legal transaction. The study based on the legal interpretation of certain provisions of the contracts showed that behind such legal transactions that are simulated towards the public, a form of corruption is hidden, based on what is called in legal science frauslegis(evading of the norms of the law). The legal consequence of legal transactions concluded in this way is the sanction of nullity. Nullcontracts are not valid and cannot produce any legal effect. In order to stop further damage to the interests of the state, and because of the fact that these decisions were voted by the Parliament of Montenegro, it is necessary, formally and legally speaking, to draft a new proposal for the decision cancelling the previous decisions, and then to start the procedure of contract termination. According to the Law on Obligations, this annulment procedure may be initiated also by the court, the public prosecutor or one of the parties. A particularly worrying fact in this context is that we were not able to obtain the data on how many proceedings for the annulment of harmful contracts was initiatedby the Ombudsman for Property-Based Interests of Montenegro. The explanation provided was that the cases of corruption are not specifically differentiated even inReport of the said institution, but that it mentions only general information on the proceedings initiated against corruption in relation to all institutions of the country. The institutions that are supposed to protect the law and the interests of the country must be in the service of the state and its citizens, and not trapped in the hands of those who undermine the foundations of the rule of law and negate the principles of legality and legitimacy.

\section{REFERENCES}

[1]Constitution ofMontenegro, 2007 '’Official Gazette, n.1/2007'. SU-SK number 01-514/22;

[2]Decision of the Tender Committee of the municipalities Bar and Budva regarding the Proposalon accepting the Contract on sale and purchase of immovable property with investment for the Location of Dubovica and the long-term lease of Kraljičina Plaža (Queen's Beach) n.08-755/3 (2014) opstinabar@bar.me

[3]Gams,A. (1972). Uvod u građanskopravo (opšti deo), Beograd 1972.,Naučnaknjiga;

[4]Law on Coastal Zone of Montenegro, 'OOfficial Gazette of MNEn.14/92',

[5]Law on Obligations of Montenegro, 'Official Gazette of MNE n.47/2008',

[6]Law on State Property of Montenegro,'’Official Gazetteof MNE n.40/11',;

[7]Ombudsman for Property-BasedInterests, Work Report for 2015, mf@ mif.gov.me

[8]Perović, S. (1990). Obligacionopravo, knjigaprva,7.izdanje, Beograd 1990. Novinarskoizdavačkaustanova, Službenilist SFRJ;

[9]Petković, V., Petković, Z. (2012). Korupcija u Srbiji, International Review (2012 br.3-4), Visoka škola za poslovnue konomiju i preduzetništvo, ISSN 2217-9739. Cobiss SR-ID 192511620;

[10]Proposal of the Decision accepting the Contract on the long-term lease of the Lastavica island with the Mamula fortress, Municipality of Herceg Novi, n.08-137/3 (2015), arhiva@ mrt.gov.me

[11]Proposal of the Decision accepting the Contract on the long-term lease of 'Kraljičina Plaža - Queen's Beach' in the Miločer park, n.08-2436/3, arhiva@mrt.gov.me

[12]Rašović, Z. (2012). Zemljišno knjižno pravo, Podgorica. Grafo Crna Gora, Notarska Komora Crne Gore, ISBN 978-9940-636-00-5;

[13]Rules of Procedure of the Parliament of Montenegro '’Official Gazette of MNEn.25/12', www.skupstina cg.me

Article history:

- Received 20 September 2016

- Accepted 12 March 2017 